Chapman University

Chapman University Digital Commons

Summer 8-15-2019

\title{
Black Women's Bodies as the Site of Malignity: Interrogating (Mis)representations of Black Women in 16th and 17th Century British Literature
}

Tonika Reed

Chapman University, toreed@chapman.edu

Follow this and additional works at: https://digitalcommons.chapman.edu/english_theses

Part of the Literature in English, British Isles Commons

\section{Recommended Citation}

Reed, Tonika. Black Women's Bodies as the Site of Malignity: Interrogating (Mis)representations of Black Women in 16th and 17th Century British Literature. 2019. Chapman University, MA Thesis. Chapman University Digital Commons, https://doi.org/10.36837/chapman.000089

This Thesis is brought to you for free and open access by the Dissertations and Theses at Chapman University Digital Commons. It has been accepted for inclusion in English (MA) Theses by an authorized administrator of Chapman University Digital Commons. For more information, please contact laughtin@chapman.edu. 
Black Women's Bodies as the Site of Malignity: Interrogating (Mis)representations of Black Women in $16^{\text {th }}$ and $17^{\text {th }}$ Century British Literature

A Thesis by

Tonika T. Reed

Chapman University

Orange, CA

Wilkinson College of the Humanities

Submitted in partial fulfillment of the requirements for the degree of

Master of Arts in English

August 2019

Committee in charge:

Mildred Lewis Ph.D., Chair

Joanna Levin, Ph.D.

Brian Glaser, Ph.D. 

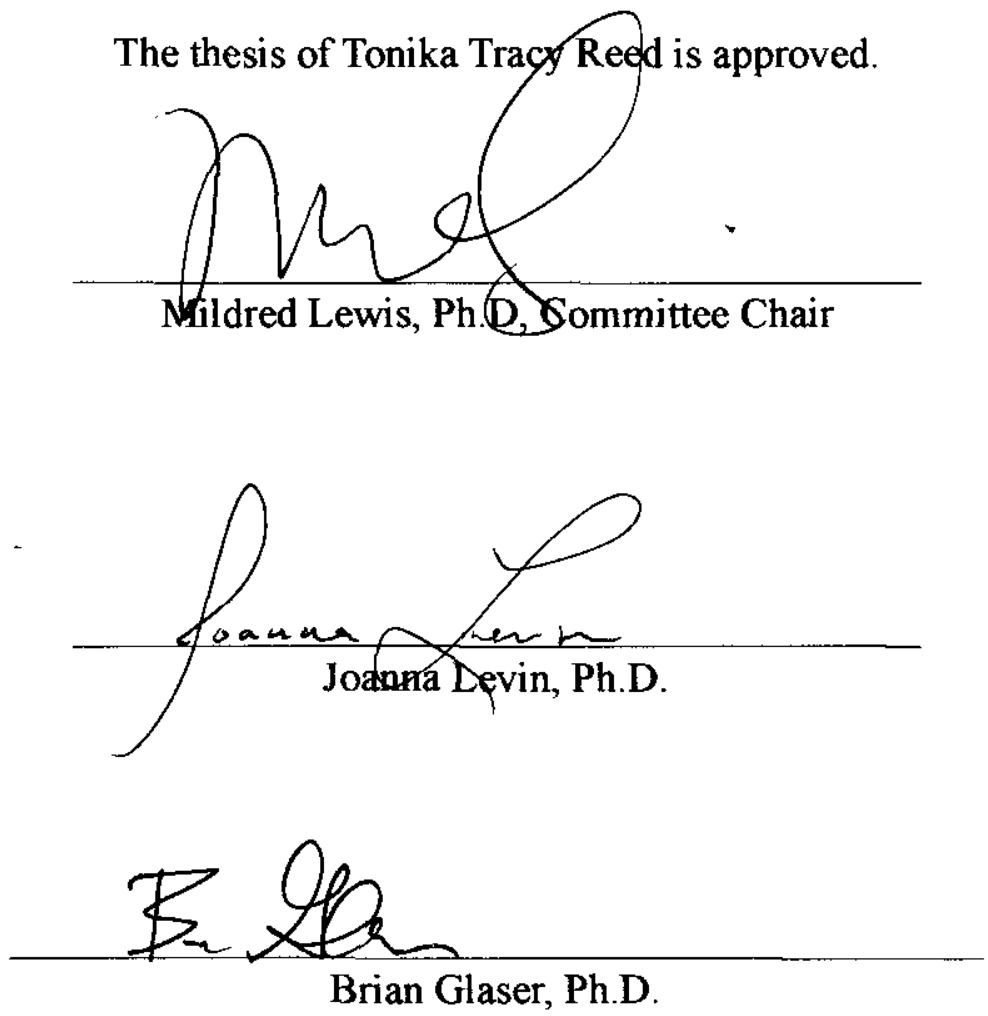

August 2019 
Black Women's Bodies as the Site of Malignity: Interrogating (Mis)representations of Black Women in $16^{\text {th }}$ and $17^{\text {th }}$ Century British Literature

Copyright (C) 2019

by Tonika T. Reed 


\section{ACKNOWLEDGEMENTS}

I am my ancestors' wildest dreams.

I would like to thank God, my mother, Jill Reed my aunt Judi Dudley, and my grandparents John and Jaqueline Dudley for raising me to be the curious, bright, and loving black woman that I am.

This thesis is especially dedicated to my aunt Joi Dudley. Rest in love, 1963-2018.

Honorable mentions:

Elizabeth and Bedelcia, my therapists.

Dr. Marta L. Carlotta for quality chiropractic care.

The OC Fire Department.

Chapman University Public Safety.

And my persistent encourager, Nana Karikari Akyempo Prempeh. 


\begin{abstract}
Black Women's Bodies as the Site of Malignity: Interrogating (Mis)representations of Black Women in $16^{\text {th }}$ and $17^{\text {th }}$ Century British Literature

by Tonika T. Reed
\end{abstract}

This thesis examines the often overlooked and consistently maligned African/black female figure in 16th and 17th Century literature. Drawing from historical contexts and feminist literary criticism, this thesis accentuates a culturally nuanced and intersectional feminist examination of specific texts from the period in question and the extent to which they inform or draw from racist rhetoric. The texts examined will include William Dunbar's Ane Blak Moir, Ben Jonson's Masque of Blackness and Masque of Beauty, and Shakespeare's Othello. 


\section{TABLE OF CONTENTS}

\section{Chapter 1}

Introduction

Literature Review

Methodology

Chapter 2

Earlier Works: Poetry and Travel Narratives

Ane Blak Moir

Chapter 3

Masque of Blackness

Chapter 4

Othello

Chapter 5

Conclusion

References

Appendices 


\section{Chapter 1}

Theyr bodies are verye smothe and clene by reason of theyr often washinge. They are in other thinges fylthy and withoute shame. Thei use no lawful coniunccion ov mariage, and but every one hath as many women as him liketh, adn leaveth them agayn at his pleasure. The women are very fruiteful, and refuse no laboure al the whyle they are with childe. They travayle in maner withoute payne, so that the nexte day are cherefull and able to walke. Neyther have they theyr bellies wimpeled or loose, and hanginge pappes, by reason of bearinge mayne chyldren. (Münster qtd in Morgan 171)

The mideval wild woman, whose breasts dragged on the ground when she walked and could be thrown over her shoulder, was believed to disguise herself with youth and beauty in order to enact seductions that would satisfy her 'obsessed... craving for the love of mortal men.' The shape of her body marked her deviant sexuality; both shape and sexuality evidenced her savagery. ( Morgan 170)

\section{Introduction}

Through literature and the power of words we cannot only explain, but debunk, demystify and reset our paradigms to give light, love, and dignity to one another and ourselves. We live by words. We thrive on them, so it is only logical to notice that we can and will also die by words. In Hortence Spiller's “Mama's Baby, Papa's Maybe” (1987) she writes: "We might concede, at the very least, that sticks and bricks might break our bones, but words will most certainly kill us" (Spillers 68). This word-induced death is what the narratives and texts of 16th and 17th century literature wrought upon the identity and dignity of black womanhood. From travel narratives to forms of literature such as poetry and plays, black women and their bodies were either partially or wholly removed from concrete narratives. And where these bodies are present, they were incredibly misrepresented to the point of dehumanization. 
In Kim Hall's seminal work, Things of Darkness: Economies of Race and Gender in Early Modern England (1995), she explains," We need new anthologies, not just of English literature but of English culture as well” (Hall 267). By setting a framework to understand early English culture, and the collective consciousness of the time, one can better approach texts, art, and other primary works from that period. It is worthy to note that the scholarly work in this area is relatively new. It is only within the last two decades or so that scholars have been having intersectional conversations about works in this period. She makes a case for how she as a black female scholar herself uses black feminist criticism without choosing to sound like an authoritative voice on blackness or femaleness within the time period her scholarship focuses on. Hall explains; "If black feminist criticism is a methodology rather than a performance of blackness, then it is in fact essential that I be able to claim a place for a black feminist book on Renaissance texts without ignoring the professional standards of black feminism as a field and without making myself the native informant on race in the Renaissance" (Hall 263). She does this by showing how Renaissance literary criticism in itself begs the question of authorial authenticity.

Following in the critical tradition of scholars like Kim Hall is relevant to the ways in which we think about our relationship to texts and how this intersects with our understandings of representation, stereotypes, etc. I was prompted to pursue my current line of inquiry while taking a class on Race and Religion in Early Modern England, in which we focused on texts by Shakespeare, Thomas Deckker, Ben Johnson, William Dunbar, etc. Reading a text like Othello, for instance, led me to certain questions of both 
personal interest and and larger academic merit. For example, since Othello was of "noble birth" who were his sisters, if he had any? What of his mother? Why was there this fascination with male Moors, and not female Moors? Surely there were women who were a part of his early life — one presumably being an actual queen, or at least someone of a high royal stature; a possibility Othello admits to when he acknowledges his noble birth. This line of questioning brought me to write a paper titled, "Curious Alchemy: Uncovering the Maligned Elements of Black Womanhood in Early Modern England", initiating my research interest in thinking about black women and their representation during this period specifically.

In that paper, I briefly touched on how we look at literary scholarship in light of the unconscious, non-overt stereotypes each reader is bringing to the texts, and if what we bring to the text affects our readings. Or whether our biases affect the worlds that we choose to create? In my Literature Review and Methodology sections I plan to explore and engage with some ideas of (mis)representation with the hope of generating alternative perspectives regarding how we read texts from the early modern period, and the implications that these texts have had and continue to have on the representations of black women.

\section{Literature Review}

The black woman has rarely been a subject of focus in critical studies of 16 th and 17 th century literature and culture. There are scarce if any writings primarily about or even exclusively authored by black women in the English language in this period. However, certain black feminist scholars have contributed seminal bodies of inquiry in 
early modern race studies specifically dedicated to the intersections of gender and race in the period. The scholars in this select pool from whom I draw include, Lynda Boose, whose article, "The Getting of a Lawful Race: Discourse in Early Modern England and the Unrepresentable Black Woman"(1994) posits the black woman as disruptive to the social, political, and economic system of the early modern period; therefore rendering her "unrepresentable"; as well as Kim Hall's seminal work, Things of Darkness: Economies of Race and Gender in Early Modern England (1995). From Hall I gleaned the newness of intersectional feminist criticism when looking at Renaissance texts, as well as how they fit into a larger picture of specifically black feminist studies in relation to representation. For a strong timeline I drew directly from the scholarship of Jennifer L. Morgan whose paper “'Some could Suckle Them Over Their Shoulder': Male Travelers. Female Bodies, and the Gendering of Racial Ideology, 1500-1770" (1997), cites white male explorers' travel innarratives; and reveals the perpetuated paradigm distortions that led directly to the justifications for Trans-Atlantic slavery. Regarding earlier writings regarding women of color during the 16th and 17th century, Jennifer L. Morgan provides us with a clear path of situating the difference of black women in early modern society. Her work provides a step by step critical cultural analysis of some of the earliest European writings regarding the "Other" (including male and female Africans and Amerindians). Elizabeth Spiller touches on the gendered binaries at play in relation to race. Spiller analyzes Aristotelian and medical mythologies that surrounded the heavily patriarchal views of miscegenation in her article "From Imagination to Miscegenation: Race and Romance in Shakespeare's "The Merchant of Venice"(1998). To help paint a 
picture of specific black women during the time period, this thesis employs the work of Kate Lowe's article "The stereotyping of Black Africans in Renaissance Europe", from a book titled Black Africans in Renaissance Europe (2005) edited and compiled by T.F. Earle.

Boose was one in a wave of preeminent scholars in the second wave of feminism to consider 16th and 17th century texts from a feminist perspective. Boose's "The Getting of a Lawful Race' appeared in Woman, "Race", and Writing in the Early Modern Period (1994). It is here she provided a framework for looking at the question of why the black female figure is seen as "unrepresentable". Boose asserts that texts which refuse to paint the picture of an autonomous or even fully present black female figure work to, "reflect the taxonomy of color through which we have come to rationalize our own racial fantasies" (Boose 35). This presents a opening for a black feminist perspective, or even a womanist perspective to come into play, which Hall provides. One of the main critiques that Hall presents of Boose's feminist criticism is that Boose claims that the discourse of race needs to be “'debrided' of its acquired meanings before discussion of its origin might fairly begin" (Hall 259). Hall explains the discriminatory history behind the meaning and usage of the word "debrided", and argues that there is no need for scholars to "seek a 'pure' category of race" (Hall 259). The eugenic notion of 'debriding' works against the feminist critique that Boose is claiming to employ. Hall presents research with a "A black feminist approach, allow[ing] for us to see the black/white dichotomy as powerful and compelling even as it competes with other discourses of 'race' in the period" (Hall 260). Hall contends with the reality that not only is this subject matter, newly informed and 
slowly, but steadily growing, but she presents readers and scholars with some of the primary texts which deal with the ambiguity of "race" during the time period. Hall writes of Boose, "She and I cannot argue that dark/fair oppositions are specifically racially charged, but it is more racialized than many critics have been willing to say. It is unclear when looking at early English culture or Shakespearean texts to differentiate between racialized and race-neutral texts" (Hall 261). Ania Loomba's article "The Color of Patriarchy” (2000), also presents a scholarship focused primarily on present patriarchal Shakespearean critiques and their treatment of race as a "secondary category" to gender. What Loomba finds in Boose's critique is a privileging of criticism that is strictly feminist and liberal. She finds there is a contention with Marxist and materialist views that results in a circularity and therefore privileging of gender over race. Loomba proffers an alternative feminist approach to early modern texts and their patriarchal implications.

\section{Methodology}

I see this book as aligned with work by women of color such as Toni Morrison, Gayatri Spivak, and Ania Loomba, who have expanded black feminism and postcolonial studies by demonstrating how these approaches can reshape both the canon and the ways we read canonical texts.

-Kim Hall, Things of Darkness p. 263

To begin my interrogation of the state of literature featuring black and African women during the Early Modern Period, my research will provide close readings of a selection of 16th and 17th century texts. These readings will be accompanied by Kim Hall's Things of Darkness (1995), and other work by scholars such as Lynda Boose, Toni Morrison, Ania Loomba, Bernadette Andrea, et.al. Even though all of these texts have been written by white males, I am choosing to frame them by a black feminist criticism- 
since these works reference, malign, and critique the black female figure/body. Each work selected includes writings on the phenotypic and social differences of the black female body. Some of the literature included are, Ane Blak Moir (1459 ), Masque of Blackness (1605), Masque of Beauty (1608), Othello (1603 ).

Similar to the work of Ania Loomba and Kim Hall, I am pushing for a more intersectional feminist criticism of these Early Modern works. I am aware that work in this area is new, and resources are scarce, but by leaning on the prominent feminist work of these scholars my own research will work to further the little work that has been done. In the vein of the work of Loomba, I will definitely state that this type of study will not result in intellectual angst, or political paralysis because of the types of bodies of which it attempts to reconstruct. There is a circularity about types of criticism that present universalist notions of knowledge or value in order to self-privilege. I am seeking to present a more inclusive and nuanced reading of these Early Modern texts to look at often marginalized and dismissed specifically black female figures; such as Barbary in Othello. “Gerda Lerner's pioneering guideline for gender critique emphasized exactly this: "all analogies- class, group, caste - approximate the position of women but fail to define it adequately. Women are a category unto themselves; an adequate analysis of their position in society requires new conceptual tools"' (Loomba 20). I agree, but I also posit that race is a challenge to the "primacy of gender"(Loomba 21). Lerner claims that women are a category of study all their own, so one may seriously consider that womanhood and blackness can be mutually exclusive, in a category all its own. With that, I am presenting no concrete "new conceptual tools", although, I will be beginning to suggest what those 
new tools may look like. One of the main things I hope that this thesis also does is to fill an absence in assumptions of some critics that here was not an African presence in Europe during pre-Portuguese slavery that began in the mid 15 th century.

I identify my project as black feminist literary criticism because it explores the interactions of race and gender in a specific cultural context, because it comes to the academy out of an oppositional consciousness, and, most important, because it is antiracist in its attempts to analyze traditional discourses and cultural assumptions that have been damaging to people of African descent. Kim Hall, Things of Darkness -p.264

\section{Chapter 2}

White Racism has been, from its origin, a story about male competition Lynda Boose, "The Getting of a Lawful Race" p.41

Thus although we may argue about the efficacy and historical accuracy of the term "race," that we literally speak a language of white supremacy may be a more obvious (though less palatable) point.

Kim Hall, Things of Darkness p.266

It is important when looking at texts from; Shakespeare, Ben Jonson, Thomas

Deckker, et al. to understand the traditions from which they draw from, because their understandings of people outside of their native England were heavily based upon a desire to silo England away from others and present with ignorance fear and monstrosity for the 'Other'. In an article titled; "From Imagination to Miscegenation", Elizabeth Spiller explains; that during the time in which England was searching for its own self definition, "there was a widely accepted medical theory [which] was a by-product of Aristotelian understandings [that the act of] conception [was] analogous to but indeed predicated on an act of intellection: monsters of the imagination result when the force of female imagination interferes with the normal model in which the idea (male) of 
conception"(Spiller 142). This quote holds the weight of sexism that ruled this time period and has persisted for years. A child was not a byproduct of an egg and a sperm, or even a product of love between two people, but the implantation of a male thought into a woman's body. This imperialist and sexist mindset of Early English society no doubt bled over into the budding English publishing scene. Should we choose to see the canon and some of its criticisms as racist, or even as heavily skewed and constricted by the writings of strictly the white male gaze; we must critically consider the origins of such ideas and modes of thought. We must further consider the extent to which these texts are not only racist, but sexist—as well as how their individual persistence may or may not depend on their interlacing.

\section{Earlier Works Poetry and Travel Narratives}

In a book titled Black Africans in Renaissance Europe (2005), Kate Lowe outlines "the role of black people as a necessary counter-image in the construction of European whiteness and "civilization" (a notion coined in the eighteenth century)" (Lowe 7-8). This book's chapters individually focus on some of the earliest art and literature in which people of color appear in 16th century European contexts. For example, the slaves of Queen Catherine of Austria, the 16th century black presence in Southern Portugal, playwright and poet Afonso Alvarez, the 'Moor's Head' by Christoph Jamnitzer, poet Juan Latino, and more. It is important to note that prior to the 16th century West Africa (specifically) may have been ahead of Europe economically and ${ }^{1}$. Europe was aroused

\footnotetext{
1 According to the Metropolitan Museum of Art, "Contrary to popular views about precolonial Africa, local manufacturers were at this time creating items of comparable, if not superior, quality to those of preindustrial Europe. Due to advances in native forge technology, smiths in some regions of sub-Saharan Africa were producing steels of a better grade than those of their counterparts in Europe, and the highly developed West African textile workshops had produced fine cloths for export long before the arrival of European traders."
} 
by West Africa's presence on the global stage, and the two entered into an abusive relationship that still reverberates to this day. Portugal had entered into slave trade with Africa around the mid 15th century, leading the way for other European countries to follow suit — resulting in the full blown presence of Trans-Atlantic slavery.

Some of the most curious texts that represent the sexist and racist origins of literature are travel narratives. Jennifer L. Morgan shows how these travel narratives actively reach toward a fetishization and desire to manipulate and control the black female body. In her work, Morgan walks readers through the narratives of Richard Ligon, Girolamo Benzoni, and Sebastian Munster. These travel narratives and others, portray Black women, Amerindian and Spanish women's bodies as sites of both ridicule and praise. In essence to a white male explorer, her "wonder situated [her] difference (Morgan 174)." A terrifying literary and social trope in need of suppression and distance; was the white male, black female narrative; the trope/narrative of a "Dark Lady". The nation defined itself by siloing itself away from "others", and by preoccupying itself with notions of a pure bloodline and hereditary fitness. Black women upset the formula of a pure bloodline. Hortence Spillers explains; "By the time of De Azurara's mid-fifteenth century narrative and a century and a half before Shakespeare's "old black ram" of an Othello "tups" that "white ewe" of a Desdemona, the magic of skin color is already installed as a decisive factor in human dealings (Spillers 70)." This reading of Spillers informed my reading of the texts in helping to understand that the way that the literature functioned was to eliminate even the possibility of a narrative of the black woman. Also, 
in the case that a black woman was represented she was a "lady in waiting, a dancer, or a prostitute" (Andrea 11).

Hall explains the heavy patriarchal hold that existed in Early Modern England briefly by stating; "The failure of the patriarchal family to restrict sexual relations before marriage causes troubles in the state as well: no "nobles or gentlemen" can find virgins to wed and thereby guarantee themselves the continuation of an untainted aristocratic bloodline" (Hall 34). English women during this time were generally found at fault if they produced a mixed child, or did not have a perfectly healthy and or easy pregnancy. It was not only the action of pre-marital sex that made white women during this time at fault of destruction, but a general male fear of the uncontrollable female mind as well. A woman's imagination was considered to be easily tainted and thus was her lineage. Hall writes; "Such fissures in the text make clear to the reader that women (in Africa as well as Europe) are the downfall of family, government, empire, and civilization" (Hall 32). For example, a lot of texts drew from biblical lore, and in John Lydgate's poem The Fall of Princes (1431-38), the serpent that tricks Adam and Eve in the garden is depicted with a female head. Women were held as responsible for the "original sin" by being the first to eat of the "forbidden fruit", and casting all of humanity into a moral downward spiral.

Not only are these sexist issues at play in these texts, but Spiller also posits that racial stereotypes are being formed and employed, whether it is prevalent in the collective conscious at that time or not. There existed, and arguably still exists, a white male fear and fascination with black female bodies; their form, productivity, and strength. This fascination is documented heavily in various travel narratives. Morgan explains that it is 
the aspect of imperialist white male competition framed within the confines of toxic masculinity that led to a divisive and oppressive English patriarchy. To stoke the fires of oppression, "Early modern English writers conventionally set the black female figure against one that was white - and thus beautiful"(167). Racism may not have had a definitive name, and other than the 'Dark Lady' stereotype neither did black women in Early Modern England.

In Pierre Boaistuau's Histoires prodigieuses, written in 1560, “a princess is "accused of adultery" after she gives birth to a child "as black as a Moor," "her husband and she both having white skin". It is found that, this child was in fact, not a result of adultery, but "was [caused by] the portrait of a Moor, similar to the child, which was customarily attached to her bed" (Spiller 143). Martin Luther, also in his Commentary on Genesis also tells a story of "a queen who gave birth to a child with the form and face of an Ethiopian as a result of a strong mental image of an Ethiopian painted on a tablet near her bed." (Spiller 141) In these narratives the royal white female is viewed as simply a vehicle for a child. She is royal, but is not seen as in control of her self-or her ability to produce the right being for her husband, and ultimately her bloodline. The black malewhite female narrative is touted as exotic and titillating. A guilty pleasure of sorts. Traditionally the blackness of a male could be cleansed or purified through the line of a white female and through assimilation. Much scholarship has been done to pose this narrative as sexist in relation to a sort of white male cuckolding fantasy (Spiller 145). Posing the black male as hyper-sexual and the white female as "dark" in regard to her devious sexuality and uncontrollable mind. 
Poetry in this time period is a good place to look when examining the racial dichotomies of the age. There is a lot of symbiotic good that poetry does while working as the basis for much more hearty texts such as plays, novels, etc. Poems are visually satiating. Within poetry there is more creative license and poetry itself can help to frame other works within the larger context. Poems such as Ane Blak Moir, Of Nigrina, In Byrrham all reflect the confusion of white men in dealing with/grappling with the vision of a female black figure. Black women upset the formula of an untainted aristocratic bloodline. They are the frightful "Other", but they are also bathed in wells of desire. It is worth noting that some scholars doubt the existence of black people living in Scottish courts during this early time period. Some claim that these women that were described as "black" were not indeed African but Islamic, white women who wore makeup/ blackface, or even women who specifically dressed in black clothing. Although several works of art and primary sources beg to differ.

Included in Hall's work is a collection of poems in the tradition of Columbia University scholar Elliot Tokson, whose dissertation titled; Popular Image of the Black Man in English drama 1550-1688 remains a highly referenced source in the field of Renaissance studies. The poems Hall includes were all written in response to a sequence initiated by the poem, Aethiopissa /A Black-Moor Maid Wooing a fair Boy. Aethiopissa ambit Cestum Diversi Coloris Virum (A Black Woman woos Cestus, a Man of a Different 
Colour) (circa 1620) is a neo-Latin poem written in the voice of a black woman begging a man she loves for sympathy because she simply cannot compete in his white world. ${ }^{2}$

Drawing from this poetic tradition, Ane Black Moir is the first poem that Hall cites. Most of the poems in the collection at the back of her book only circulated privately and were not printed until the 17th Century, which seemingly speaks directly to a level of entitlement and not necessarily shame. This poem's timeline is just shy of the time period of the Gutenberg Bible. There were not a lot of books in circulation, and the people who had them were mostly aristocratic white males. This specific work was potentially written about Elen More [Moor], a maidservant for Margret Tudor, James IV of Scotland's queen. She performed and presided over Scottish court entertainments in 1507 and 1508, specifically Jonson's masques that were designed by Inigo Jones ( Andrea 21). She was known as "The Black Queen of Beauty".

Ane Blak Moir (1507/8)

When she is clothed in rich attire, She gleams as bright as a tar barrel. When she was born the sun suffered an eclipse, The night/knight be glad to fight for her sakeMy lady with the huge lips.

Whoever for her sake with spear and shield proves the mightiest in the field, shall kiss and hold her in grips, And from thenceforth her love shall wieldMy lady with the huge lips.

\footnotetext{
2 This poem was printed and is mostly credited to religious poet, George Herbert in the early 17 th Century. See, Gilmore John T., "Aethiopissae: the classical tradition, Neo-Latin verse and images of race in George Herbert and Vincent Bourne," Classical Receptions Journal 1 (2009), 73-86, esp.82.
} 
And whoever in field receives shame

And loses their knightly name,

Shall come behind and kiss her hips,

And never to other comfort claim,

My lady with the huge lips.

Quhen schou is claid in reche apparrall,

Schou blinkis als brycht as an tar barrell.

Quhen schou was born the son tholit clippis,

The nycht be fain faucht in hir querrell-

My ladye with the mekle lippis.

Quhai for hir saek with speir and scheld

Preiffis maest mychtellye in the feld,

Sall kis and withe hir go in grippis,

And fra thyne furth hir luff sall weld-

My ladye with the mekle lippis.

And quhai in fedle receaves schaem

And tynis thair his knychtlie naem,

Sall cum behind and kis hir hippis

And nevir to uther confort claem,

My ladye with the mekle lippis.

At a first glance this poem does not mention oft described features of the "lady".

There are no mentions of her hair, her beauty, her eyes, etc. Although there are notes on

her skin tone, the size of her lips, and a mention of her hips. There are only fragmentary

descriptors here that attempt to represent her whole. There is clearly an overt level of

sexuality expressed in the poem. A sexuality that is both oppressive and exploitative.

Both the victor and the loser get to "hold her in grips", and "come behind and kiss her

hips". In the Oxford English dictionary "grips" stems from the Old English word

"grippa" noting a type of "seizing" of this woman, where her love shall be "wielded". 
She is an object that was taken either way the battle goes, and by both. She is eventually seized in an animalistic way. She has no agency, no protection.

Echoing the Greek "Four Temperaments" the first few lines give an explanation for this woman's "blackness". "she was born when the sun suffered an eclipse". Then it goes on to provide phenotypic evidence for this "blackened woman". The evidence is listed at the end of each stanza by describing her "huge lips"/“mekle lippis". In the poem a knight is fighting to win her (as is the custom of these types of poems), although the lady is described in an exploitative way for the sheer reason of her "blackness" insinuating her sexual deviance. Boose writes in "The Getting of a Lawful Race", generally speaking writing about black women in a romantic way during this century was not custom. "French troubadours did not sing about white knights enamoured of dark ladies. Except in Spain and Portugal, poets and troubadours did not make black women objects of romantic love, nor did artists depict them as such" (Boose 47). It is imperative to note that this poem is known as the "tournament of the wild [or "black"] knight and the black lady" (Andrea 55).

Similar to Shakspeare's "Dark Lady sonnets, several scholars have labeled this poem "satire", which is in some ways worse than claiming that the lady is not indeed "black" or African. Labeling these works as satire, is labeling them in a frivolous way at the very expense of black women. If it is satire, then that means that these works are looking for a way to purposefully shame and deride the potentiality of black female figures. A power play of sorts. Which I postulate it indeed is. Andrea describes this poem by describing it as; "a poem of double-edged praise that alternately celebrates Elon 
More's performance as the "Black Queen of Beauty" and bestializes her through such degrading tropes" (Andrea 259). I echo her claim that this poem at the time was a prelude for the vulgar racism to come. At the very least, Shakespeare's dark lady sonnets (which came later) describe a 'blackened' woman with references to her beauty or lack thereof, "And beauty slandered with a bastard shame" (Shakespeare 127)... and also other 'womanly' details such as her eyes, her eyebrows, her breasts, her cheeks, her scent, and even the very sound of her voice.

In Shakespeare's 'Dark Lady Sonnets' we get a glimpse of the bard riffing off of the satire of the decades before him. The woman is black, but instead of considering this in terms of racial 'blackness' many critics have explained her darkness as sunburnt, or a lady who is simply just wearing makeup. Boose writes of this notion that; "In terms of modern assumptions about Shakespeare's texts, what would happen, for example, as Jonathan Crewe has asked, if 'instead of always genteelly speaking of Shaksepeare's Dark Lady sonnets, we could bring ourselves to call them the Black Woman sonnets'? (Boose 49)"' There should be no harm in a modern critic asking or reading racial blackness into a text like Ane Blak Moir, or Shakspeare's Dark Lady sonnets because it presents a more nuanced conversation about how she functions in the text, and what power dynamics the poem is operating in. Boose also continues to cite Crewe's work; "As Crewe comments in an unpublished paper, the black woman who begins to surface as object of desire/abhorrence from no.127 onwards 'dislocates the entire system of 'white' likeness, introducing more difference than the system can manage"” (Boose 49). 
Bernadette Andrea's The Lives of Girls and Women from the Islamic World in Early Modern British Literature and Culture (2017) gets into much detail about the life and times of Elen More [Moor]. Her book purposefully "investigates the incorporation and subsequent erasure of the lives of women from Dar al-Islam in early modern Scottish and English literature and culture" (Andrea 21). Although Andrea's book gives light to these marginalized figures, she shies away from making the authoritative statement that these women are indeed of African descent. That could potentially be because of the fleeting rhetoric around what exactly early English descriptions of a person's 'darkness/ blackness' exactly meant or was. Elen More [Moor]'s legacy extends to that of Lucy Negro, the 'Tartar girl' of Queen Elizabeth I's, and Lady Teresa Sampsonia Sherley. ${ }^{3}$

Elen More (H)elen Moor was a "Black woman from Islamic West Africa, who participated in the Scottish King James IV's pageants at the turn of the sixteenth century (Andrea 54)". She appeared in several of the king and queen's masques, and also inspired one of William Dunbar's “double edged”(Andrea 55 ) poems (Ane Blak Moir). One must note that her stature in the court was potentially more of a "lady-in-waiting than that of a chattel slave" (Andrea 55) — which is not to negate any potential mistreatment.

Bernadette Andrea connects Elen to that of Lucy Negro (Black Luce), another West African woman who ran a brothel in Clerkenwell, London. Lucy Negro was also rumored to have inspired Shakspeare's two dozen "Dark Lady" sonnets (Andrea 56). Andrea also

\footnotetext{
3 Andrea, Bernadette. "The Islamic World and the Construction of Early Modern Englishwomen's Authorship: Lady Mary Wroth, the Tartar-Persian Princess, and the Tartar King." The Lives of Girls and Women from the Islamic World in Early Modern British Literature and Culture, Toronto, University of Toronto Press, 2017, 49.
} 
explains that it is probable that the idea of a "Black Queen"_- "quean" or "a prostitute" was a common pun in Shakespeare's era, RE: The Comedy of Errors.

Celia Daileader further expands the poetic erasure and frivolous marginalization of black women in her book Racism, Misogyny, and the "Othello" Myth: Inter-Racial Couples from Shakespeare to Spike Lee (2005), by stating that an erased and often overlooked narrative identity of the black woman in early modern England is of a "secondary more theoretical thesis... that is, the suppressed counter- narrative of the black woman seduced or raped by a white man or men" (Daileader 15). When black women do show up in these texts instead of being a vital part of the narrative, they are often portrayed as afterthoughts, vehicles for humor and or appear for the purpose of pregnancy" (Daileader 15). Daileader explains, “The notion of 'washing the Ethiope,' indicating an exercise in futility, is only one [reference of white washing and deliberate ]. Another such expression is "Pitch defiles." Pitch defiles; it does not just dirty; and it does so by physical contact. Moreover it does not merely rub off on someone; rather, it sticks" (Daileader 4). This idea of "tainting', or "blackness" being touted as something that can be rubbed off/onto someone is clear in works like Masque of Blackness.

\section{Chapter 3}

\section{Masque of Blackness}

With England's preoccupation in this era with notions of pure bloodlines and hereditary fitness, the few representations that we see of black women at this time are not only problematic, but absurdly dismissive. Ben Johnson's Masque of Blackness is the tale of a group of "African” women (played by Queen Anne and her court in blackface) who 
travel to "Brit-tania" where they will search in hopes of finding a specific sun god who can help them turn into white women. This text is vital to this research because at the time Queen Anne was essentially England's beauty standard. Bernadette Andrea writes of Jonson's work that she believes the text "refuses [a] disavowal of women's sexual and textual agency. Rather than endorse the division between privileged whiteness and suspect blackness, which lies at the heart of the emerging early modern norm of "fair" white beauty, the Queen collapses this dichotomy by deliberately staining her skin black and presenting herself and her ladies as "black beauties." (Andrea 248) For Queen Anne to depict blackness was a serious power move, because yes, it did make a mark for her as queen. She was attempting to resist on behalf of English women's sexual and textual agency by performing while pregnant, being involved in the authoring process of the play, and performing in blackface (which was seen as abominable). Although I do not agree with Andrea that the masque does does not endorse division, it very much makes clear to me that the division was purposeful. For Anne to depict blackness as something that needs to be 'washed away' is reflective of the collective consciousness of early modern England. These masques were performed specifically for Scottish/English aristocrats, and the costume and set design were created by Inigo Jones, a prolific architect.

As of one Phaëton, that fired the world,/And that, before his heedless flames were hurl'd About the globe, the Æthiops were as fair/ As other dames ; now black, with black despair : And in respect of their complexions chang'd,/ Are each where, since, for luckless creatures rang'd -Masque of Blackness, Ben Johnson 
This passage claims Æthiops (Africans) were fair/white before Phaeton, the son of Helios, came and tried to drive his dad's chariot, but crashed and set the whole earth on fire. In other words, these daughters were fair until Phaeton's drastic error. . As a result of Phaeton's mistake, Æthiops were now to go and fix their complexions by getting another sun god to turn them back to their original fair state. Reading this passage in the context of our current modernity presents the idea of a reinforcing colorism, whitewashing, and colorblindness. Even though at this time in early modern England constructions of racial discrimination where not exactly fixed or set in stone systematically, one could make the argument that this masque was "not about race", but more about gender stereotype subversion. Andrea posits that "conjunction of "blackness" and "beauty" in British culture remained fluid throughout the sixteenth and into the seventeenth century: hence, "blackness" could signal both beauty and abjection, although in distinctly problematic ways" (Andrea 249). Much like in the poetry of the time; "blackness" was a centre of dichotomy. Andrea goes on to explain how "Jonson records that the governing idea of his first masque with Queen Anne, The Masque of Blackness, was determined by the Queen's "will" to have the masques's protagonists "blackamores at first" (Andrea 252). She states that "his art gave form to her caprice" (Andrea 252). Therefore it was her idea to pursue political and sexual dominance by portraying herself and her court as "blackamores". If she could even make black beautiful, she deserved to be the white queen that she was.

The play bolsters the collective idea at the time that those who are not 'fair' are to be feared and converted back, or "set right". What is taking place here is the same "washing" of a "blackness" and moral "washing" of women in general. Although males, 
white or black have no such essential to be "washed" and or "moral". Lynda Boose writes; "The cultural imperative of both masques is turning females white: none of the male "Blackamoors" seems to feel any such need" (Boose 50). Andrea references Hall when speaking about The Masque of Blackness and explains that Hall sees the masque as, “"a defining moment of the British empire that used blackness to privilege white beauty"; and I agree. This can be read as such. Yet, the masques also both can operate as ““catalyzing agents for a discursive network of 'blackness,' which participated in the process of identity and empire formation by dramatically reconfiguring issues of racial/ cultural identity and gender difference"(Andrea 269 ) Reading the text in this way does suggest a "complex model of cultural configuration," and shows that a new hegemony is arising.

Save your chaste thoughts, with reverence, steep/Your bodies in that purer brine,/ And wholesome dew, call'd ros-marine :/Then with that soft and gentler foam,/Of which the ocean yet yields some/Whereof, bright Venus, beauty's queen,/Is said to have begotten been,/You shall your gentler limbs o'er-lave,/And for your pains perfection have :/So that, this night, the year gone round,/You do again salute this ground ;/And in the beams of yond' bright sun,/Your faces dry, - and all is done. -Masque of Blackness, Ben Johnson

This closing passage is curious in that it urges the women as they are being 'washed' of their black iniquity to 'save chaste thoughts', and 'steep their bodies in purer brine'. This speaks directly to the fact that the presence of blackness was not only one of phenotypic difference, but also of moral impurity. Their skin needs to be changed so that they can reflect their true pure feminine power, specifically that of "bright Venus, beauty's queen". This needs to be done, not for their own sake, but so that they can "again salute this ground"- the ground of their male counterparts. Similar to that of the 
woman in Ane Blak Moir, these women lack agency. They are being asked to become 'whitewashed' so that they can be pure and properly feminine.

In Andrea's The Queen's Masques there is a citation of a critique of this performance from junior diplomat Dudley Carleton. The critique appears in a letter to the current Secretary of State, and senior diplomat, Sir Ralph Winwood. The critique explains Carleton's distaste for the masque and also echoes the fact that the play eventually was disastrous for the queen's reputation. The critique reads:

Their apparel was rich, but too light and curtizan-like for such great ones. instead of vizzards, their faces, and arms up to the elbows, were painted black, which was disguise sufficient, for they were hard to be known; but it became them nothing so well as their red and white, and you cannot imagine a more ugly Sight then a troop of lean-cheek'd Moors (Andrea 265).

Carelton goes on to discuss how disgusted he was with Anne performing while pregnant and in blackface. Boose explains that there are two revealing things about his description; "his fantisized sense of a 'Danger' that female blackness will leave marks on the white male who touches her", and the way that his "anxiety is immediately followed by a curiously punitive narration that depicts the 'Night's Work' culminating in 'furious assaults' that tore down 'Tresses' within the great chamber (Boose 51). Essentially Carelton believes that Anne has disgraced the very nation of Europe with this performance. He will not stand for it.

It is clear that "the Queen's privileged "whiteness" is shaped by a disturbing history of royal "spectacles of blackness" in the sixteenth-century Scottish and English courts" (Andrea 248), bolstering the idea that there may have not been a specific construction of "race", but stereotypes of phenotypic difference were commonplace. 
Claiming that these works are satire absolutely does not exempt the works from the confirmation of overt stereotypes and blatant bias. Andrea cites how Hardin Asand and Barbra Keifer Lewalski's models of textual production and court power explain the function of Early modern women's actions and statements. "As Asand conclueds, "The Masque of Blackness, on several levels, is a document of marginalization, and it records analogically, historically, and ethnically, the intersection of socially excluded forces"''(Andrea 254). Andrea even cites Morrison's statements about scholarly indifference from Playing in the Dark: Whiteness and the Literary Imagination. "Toni Morrison stresses in the epigraph to this essay, "to see meaning in the thunderous, theatrical presence of black surrogacy" as "an informing, stabilizing, and disturbing element" in these early modern cultural productions and in the overall production of early modern culture" (Andrea 255). Jonson's next masque with Queen Anne was to show the ladies in their 'pure white skin'. To present themselves as cleansed.

\section{Chapter 4}

\section{Othello}

Let's face it. I am a marked woman, but not everybody knows my name. "Peaches" and "Brown Sugar," "Sapphire" and "Earth Mother," "Aunty," "Granny," God's "Holy Fool," a "Miss Ebony First," or "Black Woman at the Podium": I describe a locus of confounded identities, a meeting ground of investments and privations in the national treasury of rhetorical wealth. My country needs me, and if I were not here, I would have to be. Hortence Spillers, Mama's Baby, Papa's Maybe: An American Grammar Book (pg. 65)

At the time Othello debuted on the national stage, it was one of many plays in which Africans were being portrayed. In our current climate, Othello is often deemed the 
Shakespeare text 'about race'. Loomba spoke on the notion of studying race in Othello as something that can be more polarizing to the field of Renaissance studies and current higher education classroom climates by stating;

The notion of "race" must transcend the black presence in the plays and inform understandings of gender, the state, political life, and private existences, otherwise the "others" within Shakespeare as well as in the Shakespearean academy or classroom will be granted only a token legitimacy which will disguise, among other things, the dynamic and intricate intersections of these categories in the creation of Renaissance culture as well as our own contemporary cultures. (Loomba 26)

Hall writes, "The contingency of race also suggests that critics and teachers of Renaissance texts need to be much more flexible and subtle in their identification of language and images as "racialized" or "race-neutral" (Hall 261)". Both Loomba and Hall beg the legitimacy of a black feminist reading of this text. Applying this type of criticism would "extend the notion of "race" and will push critics, teachers, and students alike to be more flexible in how they analyze the text in terms of racial and gendered dynamics also (Hall 261)”. In 'The Color of Patriarchy' Loomba cites the work of Stephen Greenblatt, and brings up a vital point about there being a tendency to read a text with a more fluid eye, and a more categorically open criticism. Greenblatt states that there is a "tendency... in those explicitly concerned with historical or ideological functions of art to ignore the analysis of pleasure or, for that matter, play" but goes on to caution that "transhistorical stability or continuity of literary pleasure is an illusion... the task then would be to historicize pleasure, to explore its shifts and changes, to understand its interests (Loomba 24)." 
In agreement with these scholars there are a few specifically curious passages in Othello that I would like to draw attention to. The first passage works to set up a general framework for the racial context of the text. The very first time we see Othello's blackness described is by Iago and Roderigo. And the text reads thus;

"And I-God bless the mark! — his Moorship's ancient. RODERIGO. By heaven, I rather would have been his hangman. IAGO. Why, there's no remedy. 'Tis the curse of service, Preferment goes by letter and affection, And not by old gradation, where each second Stood heir to the first. Now, sir, be judge yourself Whether I in any just term am affined To love the Moor.

RODERIGO. I would not follow him then.” (1.1 33-41)

Iago's disavowal of Othello sets up the racial framework for the text. Before we even see Othello appear, we know that he is black and disliked for his stature and years of military service. Roderigo essentially says that he rather would have been his 'hangman' or his executioner. "Iago circulates the most explicit and negative visions of Moors as lascivious, duplicitous, vengeful, superstitious, and jealous," (177). As the audience is learning about this Moor of Venice, they are receiving conflicting reports on his character. Eventually we hear Othello speak for himself, about himself to the Duke and others.

OTHELLO. Let him do his spite.

My services, which I have done the signiory, Shall out - tongue his complaints. 'Tis yet to knowWhich, when I know that boasting is an honor, I shall promulgate-I fetch my life and being From men of royal siege, and my demerits May speak unbonneted to as proud a fortune As this that I have reach'd. For know, Iago, But that I love the gentle Desdemona, I would not my unhoused free condition 
Put into circumscription and confine

For the sea's worth. But, look! What lights come yond? (1.2)

It is here that the audience learns that Othello is not just a normal Venetian. He is of 'royal siege' and he has done lots of work in the military, so much that his reputation precedes him. Boose describes Othello by saying; essentially "Othello is a Venetian (Boose 38)." He was a converted Christian, has adopted the language of the Venetians, and even imagines himself in battle with the same enemy. It is here one can begin to question, if he is a 'Moor' and of 'royal siege', what did that side of him look like. Originally titled Othello, the Moor of Venice, we can ask; "What possibilities of affinity and difference does th[is] title suggest?"(177)

Desdemona (Othello's wife), who is often referred to as 'gentle' and 'fair' describes Othello as not being capable of jealousy because the sun has "Drew all such humors from him" (3.4.25). It is here a phenotypic stereotype is established. This concept of the "sun drawing humors" stems primarily from the idea that those born in certain parts of the world possessed certain different temperaments - likely adopted by Shakespeare from the Greco-Roman variation of 'The Four Temperaments' (RE: Ane Blak Moir) It is important to note that; "Desdemona, apparently once frightened by his darkness, has found his humanness in the stories of his suffering; (Boose 38)." Desdemona seems aroused by the history and sexual deviance that Othello's dark skin implies. Boose writes, “...the black male— white female union is, throughout this period and earlier, the most frequently depicted as the ultimate romantic-transgressive model of 
erotic love" (Boose 41). This type of 'erotic love' is exclusionary toward that of black women and or female Moors.

The main passage in this text I want to reference deals with an often glossed over character. The passage on Barbary. Barbary is Desdemona's mother's maid. She is an African woman whose very name describes her origin; at some level, she is the origin. She is mother Africa and acts as a foil for the coming destruction of Desdemona's character. She plays no active part in the text because when she is present she is dead. It is a fair, Venetian woman; Desdemona, who evokes Barbary's song and her presence in the text altogether. It is curious to note that Barbary's very voice is even co opted for the purpose of white female sympathy. Lots of critics have made connections between Barbary and the Barbary horse that Iago references in Act 1 Scene 1. There are even translations that name her Barbarie (Old English), or Barbara. The name Barbara seems problematic in that it does not reference the coast from which she and or Othello originate. This further begs the question — was Barbary even a black woman to begin with? The complications that this presents are relevant to the conversation of what exactly a 'Moor' was defined as. "The widespread use of Moor to refer to both religious and physical difference means that the word proves incredibly elastic, stretching to encompass a wide range of peoples and cultures" (177)

"My mother had a maid called Barbary./ She was in love, and she loved proved $\mathrm{mad} /$ And did forsake her. She had a song of "Willow."/An old thing 'twas, but it expressed her fortune,/ And she died singing it: that song to-night/Will not go from my mind" (4.3.23-31). 
There are no real details of Barbary's "interior" or even "anterior" life that readers can visibly see and interact with. In my research I struggled to find information on specifically Barbary as a character in Othello, and or this very passage. Her name and connection to the Barbary horse are all that we have to go on that she is indeed an African woman. Also, considering the literary tradition of this time, it is absolutely plausible that there was an African maid that Desdemona grew up with. Lynda Boose noted this absence in The Getting of a Lawful Race, but instead of showing where these black women were present, she briefly reflected on their absences. Boose writes that it is within "the person of the black woman that the cultures pre-existing fears both about the female sex and about gender domainance are realized (Boose 46)."

Barbary's silenced narrative inadvertently touts the glorified romance of a black man- (who is consumed with respectability politics to the point in which he cannot think outside of them) being paired with a white, Venetian woman of nobility. Maybe it is just that as Boose frames this once again; "the black male-white female union is not the narrative that requires suppression" (Boose 45).

DESDEMONA. I have much to do

But to go hang my head all at one side And sing it like poor Barbary. Prithee, dispatch.

EMILIA. Shall I go fetch your nightgown?

DESDEMONA. No, unpin me here.

This Lodovico is a proper man.

EMILIA. A very handsome man.

DESDEMONA. He speaks well.

EMILIA. I know a lady in Venice would have walked barefoot to

Palestine for a touch of his nether lip.

DESDEMONA. [Sings.]

"The poor soul sat sighing by a sycamore tree, 
Sing all a green willow;

Her hand on her bosom, her head on her knee,

Sing willow, willow, willow.

The fresh streams ran by her, and murmur'd her moans,

Sing willow, willow, willow;

Her salt tears fell from her, and soften'd the stones- -"

Lay by these-

[Sings.] "Sing willow, willow, willow—"

Prithee, hie thee; he'll come anon-

[Sings.] "Sing all a green willow must be my garland.

Let nobody blame him; his scorn I approve- -

Nay, that's not next. Hark, who is't that knocks?

EMILIA. It's the wind.

DESDEMONA. [Sings.]

"I call'd my love false love; but what said he then?

Sing willow, willow, willow.

If I court moe women, you'll couch with moe men-"

So get thee gone; good night. Mine eyes do itch;

Doth that bode weeping?

From the choice of tree, to the woman in the song's very posture, a reader or audience member can feel the somber tones of this song. A song that oozes of death and ominous presence. A song that droops and sways in the wind like a willow tree itself. The woman in the song moans as 'fresh streams' flow by her. Beauty and newness are not what she is concerned with. She murmurs and moans, a wailing woman. Salt tears, and stones, she is hoping for a man that will never come around. She approves his scorn; meaning she understands why he doesn't want her. She understands why he would reject her presence even. She claims that he doesn't even love her; "I call'd my love false love". Also, she knows that she could never be with anyone else, so his claim that she would s will indeed sleep with other men is preposterous and is the very thing that breaks her heart.. So he should leave to let her rest so she can continue to weep. 
This song is deemed "Shakespeare's Saddest Song” by the Shakespeare Birthplace Trust. In this scene, often called the "Unpinning scene" because she is preparing for bed, Desdemona is frustrated with Othello for thinking that she had been unfaithful. While talking to Emelia, she begins to sing the ominous Willow Song. The Willow Song is taken from a book of lute music, printed in 1583 . The song was originally about a man who died because his lover was cruel and betrayed him, therefore we can infer that the audience may have known the song and knew that it was a predictor of tragedy. Shakespeare changes the song to be about a woman, but he doesn't necessarily just make it about Desdemona. It is here he adds in the third dimension of Barbary. Denise A. Walden wrote in Shakespeare Quarterly about how this vision of Desdemona and Emelia in the "Unpinning Scene" is to provide sympathy for Desdemona; "By delving deeply into her feelings, it portrays an active and tragically nuanced Desdemona and raises empathy for her with its psychological exposé (Walden 487).” The idea of placing Barbary’s 'Willow Song' among Desdemona’s undressing is to show her vulnerability. This vulnerability is reflected through to describe the woman that is Barbary. It is curious that Desdemona remembers Barbary here and not in any other places of the text. 


\section{Chapter 5}

\section{Conclusion}

This thesis highlights the nuanced yet persistent erasure and debasement of African and black womanhood in 16th and 17th century literature and its interwoven gender and racial implications. In doing so, the aim is to set the stage for initiating further inquiry into research about black women's bodies and their marginalization within early modern literature. More research should be done regarding this ongoing cycle of malignity and the implications of racist rhetoric. It is worth noting, that invaluable work relating to this exist, especially within the authorial traditions of African American women writers and scholars like Audre Lorde and Toni Morrison, but to name a few.

Audre Lorde explains in her essay, Scratching the Surface: Some Notes on Barriers to Women and Loving, "For Black women as well as Black men, it is axiomatic that if we do not define ourselves for ourselves, we will be defined by others- for their use and to our detriment" (Lorde 45). We see each other through distorted lenses, and in this present moment, we are beginning to be able to clearly and concisely explain those distortions. Lorde goes on to explain these distortions by stating, "This jugular vein psychology is based on the fallacy that your assertion or affirmation of self is an attack upon my self - or that my defining myself will somehow prevent or retard your self definition" (Lorde 51).

In order to begin the journey of self definition we must build up a reservoir of people, experiences, things, spaces, and thoughts to guide our self definition. My thesis will work to discover some of the literature based origins of paradigm distortion and how 
these relate to our assumptions regarding and, in turn, our treatment of one another and black women specifically.

Humanity should be a quality, if not of the writing itself, then of the transaction between writers and reader. Good writing is alive and organic, an inner-voice conversation between a human writer and a human reader, Words on screen may appear to be inanimate objects, but what they convey and represent is fully alive. Writers enter into an interlocking dynamic commerce with their sources, their subjects and their readers; and they should approach the transaction with respect and solicitude (Stepp 5).

I agree with Boose in that, "given feminism's very different historical relationship to "history," it seems thoroughly consistent with the feminist goal of liberating women form their history that the mainstream feminist interpretations of Shakespeare did indeed marginalize the historical and concentrate instead on the literary text (Loomba 22:

Boose's words)." At some level liberating women requires a rewriting of history. There is a type of healing that must begin in looking at these texts in light of their most marginalized characters, black women. In this same vein; "healing does not deny the construction of bodies, but instead suggests that they can be constructed differently, for different ends (Griffin 524). Work in this field that presents a more intersectional and inclusive view of these texts can bleed over into shaping the minds of readers and providing a more fulfilling and cathartic educational experience for young scholars and researchers. In the words of Hall; "If we are successful, we can give students the critical tools for a more meaningful and complex dialouge on race, one that comprehends the intersection of categories without disregarding our differences and that moves beyond racial guilt-- but not beyond justice (Hall 268). In examining these texts and locations in which black women are marginalized and or overlooked, we can continue in the process 
of examining inherited literary biases. My hope is that I have successfully made my research accessible by approaching each text through a black, feminist, and heuristic method of examination and criticism. "The key difference is that the black feminist is expected to bring a reading practice or epistemology derived from personal experience and historical knowledge to the texts and lives of black women"(Hall 262).

In conclusion, all of these Early Modern texts echo a similar narrative about black/African women. In the eyes of poets at this time black women are beautiful, but only frighteningly so. Black women are 'cursed' or in need of conversion, and that black women are sexual objects to be had and fetishized. The only way they can rid themselves and become 'normal women' is to be washed of their blackness. The promotion of the 'fair' skinned race in Early Modern England soon crosses the sea when the bricks are set and laid out to build America. We gloss over the fact that not much changes in the assumptions of inferiority and hyper sexualization about black and African women. 


\section{References}

Andrea, Bernadette. "Black Skin, The Queen's Masques: Africanist Ambivalence and Feminine Author(Ity) in the Masques of Blackness and Beauty." English Literary Renaissance, vol. 29, no. 2, 1999, pp. 246-281.

Baker, Russell, and William Zinsser. Inventing the Truth: the Art and Craft of Memoir. Houghton Mifflin Company, 1995.

bell hooks. Aint I A Woman. Boston, MA: South End Press, 1981.

Boose, Lynda E. "The Getting of a Lawful Race: Racial discourse in early modern England and the unrepresentable black woman" 1948- Women, "race," and writing in the early modern period. Routledge, London; New York, 1994.

Daileader, Celia R. Racism, Misogyny, and the "Othello" Myth: Inter-Racial Couples from Shakespeare to Spike Lee. Cambridge University Press, 2005.

Davis, Angela Yvonne. Women, Race, \&Class. New York, The Women's Press, 1994.

E. Patrick Johnson. Appropriating Blackness: Performance and the Politics of Authenticity. Durham and London: Duke University Press, 2003.

Gilmore John T., "Aethiopissae: the classical tradition, Neo-Latin verse and images of race in George Herbert and Vincent Bourne," Classical Receptions Journal 1 (2009), 7386.

Griffin, Farah Jasmine. “Textual Healing: Claiming Black Women's Bodies, the Erotic and Resistance in Contemporary Novels of Slavery." Callaloo 19, no. 2 (1996): 519-36.

Hall, Kim F. Things of Darkness: Economies of Race and Gender in Early Modern England. Cornell University Press, 1998.

James A. Knapp. Image Ethics in Shakespeare and Spencer. New York, Palgrave MacMillan, 2011.

Johnson, Ben “The Masque of Blackness” https://modernforms.org/wp-content/uploads/ Ben-

Jonson- Masque-of-Blackness-Text.pdf

Korhonen, Anu. "Washing the Ethiopian white: conceptualizing black skin in Renaissance England”, Black Africans in Renaissance Europe. Cambridge University Press, 2010. 
Lorde, Audre. Sister Outsider: Essays and Speeches. Crossing Pr., 1984.

Morgan, Jennifer L. "'Some Could Suckle over Their Shoulder': Male Travelers, Female Bodies, and the Gendering of Racial Ideology, 1500-1770." The William and Mary Quarterly, vol. 54, no. 1, 1997, p. 167.

Niebrzydowski, Sue. "The Sultana and Her Sisters: Black Women in the British Isles before 1530.” Women's History Review, vol. 10, no. 2, 2001, pp. 187-210.

Robert Bucholz and Newton Key. Early Modern England 1485-1714: A Narrative History. Malden, MA: Blackwell Publishing, 2004.

Shakespeare, William, and Kim F. Hall. Othello, the Moor of Venice: Texts and Contexts. New York, Palgrave Macmillan, 2007.

Shakespeare, William, Sonnets 1 and 127

Spiller, Elizabeth A. "From Imagination to Miscegenation: Race and Romance in Shakespeare's The Merchant of Venice."” Renaissance Drama, vol. 29, 1998, pp. 137 164.

https://thewalters.org/wp-content/uploads/revealing-the-african-presence-in-renaissanceeurope.pdf

Williams, Carla. Black Venus 2010: They Called her "Hottentot." Philadelphia, PA, Temple University Press, 2010.

https://reviews.history.ac.uk/review/619

https://www.metmuseum.org/toah/hd/aftr/hd_aftr.htm 


\section{APPENDIX A \\ An Ethiopian Woman Woos Cestus, A Man of Different Color (English Translation) \\ What is it to me, if my face is black? Night is no less loved for that. \\ The traveler's forehead is always burnt;}

And the girl who pines over you has a long journey. If the land is black, who despises the furrow?

Close your eyes! You will see only black.

Then open them and see the dark shadow of my body. I can do that little thing for you.

Don't you realize that the smoke of my face

Conceals the flame of passion in my heart? You will not relent?

Then my sad dark cheeks are a presage of my sorrow

\section{Aethiopissa ambit Cestum Diuersi Coloris Virum \\ (Original Latin Version) \\ Qvid mihi si facies nigra est? hoc, Ceste, colore \\ Sunt etiam tenebrae, quas tamen optat amo}

Cernis vt exustâ semper sit fronte viator; Ah longum, quae te deperit, errat iter.

Si nigro sit terra solo, quis despicit aruum? Claude oculos, \& erunt omnia nigra tibi:

Aut aperi, \& cernes corpus quas proijcit vmbras; Hoc saltem officio fungar amore tui.

Cum mihi sit facies fumus, quas pectore flammas Iamdudum tacite delituisse pûtes $P$

Dure, negas? O fata mihi praesaga doloris, Quae mihi lugubres contribuere genas! 


\section{APPENDIX B}

The idea of a 'Black Venus' didn't take shape until the end of the 18th Century, but is a good reference point for how Europeans viewed the black female figure in both literature and the real world as well. (Sara) Saajtjie Baartman (AKA Hottentott Venus) was born in 1789 and passed in 1815. She was paraded around in European "freak shows" for people to pay and ogle at the 'monstrosity' of her body. Even after Baartman had passed her brain, skeleton, and sexual organs remained on display until 1974 in Paris at a museum. Eventually her remains were buried and ceremonalized in her native South Africa in 2002. Baartman was one of many 'hypersexualized women’ whose black sexuality was iconographic in nature. These women portrayed in these shows, paintings, sculptures, and other forms of art helped form the ideological rationale for English expectations and anxieties about encountering the black female "other", as well as other marginalized peoples such as Native Americans, and many other indigenous peoples.

Charles Baudelaire's 'Black Venus', Jeanne Duval ("Sorceress with the ebony thighs, child of black midnights,"), the bronzed ancestral Queens of Benin (which were later stolen and imported to Europe for museum purposes), The Black Madonnas, etc.

The association of the black with concupiscence reaches back into the Middle Ages.The twelfth-century Jewish traveler Benjamin of Tudela wrote that "at Seba on the river Pishon ... is a people ... who like animals, eat of the herbs that grow on the banks of the Nile and in the fields. They go about naked and have not the intelligence of ordinary men. They cohabit with their sisters and anyone they can find. ... And these are the Black slaves, the sons of Ham." The black, both male and female, becomes by the eighteenth century an icon for deviant sexuality in general, almost always, however, paired with a white figure of the opposite sex.

Black Venus 2010: They Called her Hottentot (Gilman 15) 